Вестник ЧГПУ им. И.Я. Яковлева

Серия: Механика предельного состояния. 2021. №2 (48). С. 3-6

C. А. Матвеев

\title{
О ВКЛАДЕ ПРОФЕССОРА Ю. В. НЕМИРОВСКОГО В ДОРОЖНУЮ НАУКУ
}

Сибирская государственная автомобильно-дорожная академия, г. Омск, Россия

DOI: $10.37972 /$ chgpu.2021.48.2.001

Армирование элементов строительных конструкций и грунтовых оснований геосинтетическими материалами применяется уже более полувека. Геосинтетические материалы используют для армирования дорожных одежд и грунтов земляного полотна, при устройстве подпорных стенок, для предотвращения оползней и укреплении откосов, при проведении противоэрозионных мероприятий, а также для обеспечения дренажа.

Применение геосинтетики в транспортном строительстве позволяет компенсировать недостатки свойств грунтов и дорожно-строительных материалов, повысить их физические и механические свойства, а в некоторых случаях - превратить в совершенно новые типы материалов.

Теоретические основы расчёта армированных геосинтетическими материалами конструкций базируются на методах расчета плит на упругом основании и изгибаемых слоистых систем. Большой вклад в развитие данного направления научных исследований внес профессор Ю.В. Немировский.

Общим недостатком существующих подходов при расчете дорожных одежд являлось привлечение традиционных методик расчёта конструкций со сплошными, однородными, изотропными слоями для расчёта армированных и по существу конструктивно анизотропных конструкций. Армированный геосинтетическими материалами грунт по существу представляет собой новый композитный конструктивноанизотропный материал, обладающий управляемой анизотропией, которая зависит как от свойств грунта, так и от свойств армирующей структуры. Данное направление, основанное на структурном подходе и касающееся вопросов армирования не только грунта, но и любого материала, используемого в дорожном строительстве, получило развитие в совместных работах Ю.В. Немировского и автора этих строк, выполненных под патронажем Юрия Владимировича.

(C) Матвеев C. А. 2021

Матвеев Сергей Александрович

e-mail: dfsibadi@mail.ru, доктор технических наук, профессор, Сибирская государственная автомобильно-дорожная академия, г. Омск, Россия.

Поступила 21.03.2021 
Так, в работе [1] Юрием Владимировичем была предложена расчётная модель армированного объёмной георешёткой упругого слоя в виде набора стандартных элементов - характерных ячеек, которые должны были вести себя как некий композитный анизотропный материал, свойства которого зависят как от свойств основного материала слоя, так и от свойств армирующей структуры, её геометрической формы, размеров и расположения относительно исходных осей. Исходя из законов термоупругого деформирования основного материала слоя и материала армирующих элементов были получены выражения для определения упругих постоянных и коэффициентов линейного температурного расширения эквивалентной композитной анизотропной среды. Оценка влияния армирования на упругие постоянные армированного слоя показано путем сравнения матриц упругих характеристик армированного и неармированного слоя.

На основании структурного подхода в работах [2-4] исследовано влияние геометрических параметров армирующей структуры на упругие характеристики композита "грунт-георешетка", работающего в условиях объемного и плоского напряженного состояния. Теоретически установлено, что при уменьшении размеров характерной ячейки георешетки эффект армирования возрастает многократно.

На основании полученных результатов была разработана изложенная в работах [57] теория многослойных конструктивно-анизотропных плит на упругом основании, сопротивляющемся сжатию и сдвигу. Каждый слой плиты имеет индивидуальную структуру армирования в виде объемных георешеток, плоских геосеток и прослоек из геотканей. Построена общая система разрешающих уравнений продольно-поперечного изги6а многослойной плиты. Для частного случая цилиндрического изгиба получено аналитическоское решение, которое доведено до числовых результатов и представлено на графиках, отражающих влияние армирования отдельных слоев и трения между полиармированной плитой и основанием на деформативность дорожного покрытия.

В работах $[8,9]$ представлена расчетная модель и теория термоупругого деформирования многослойных плит, армированных плоскими георешетками.

В статье [10] представлена предложенная Ю.В. Немировским и совместно разработанная теория расчета на статическую нагрузку и температурные воздействия многослойной дорожной конструкции в виде насыпи земляного полотна со слоями, армированными произвольным набором геосинтетических материалов. Расчетная модель конструкции рассмотрена в рамках плоской задачи теории упругости с привлечением рядов Фурье. В качестве примера приведен расчет на статическую нагрузку двухслойной конструкции, верхний слой которой армирован объемной георешеткой. Результаты расчета сравниваются с результатами натурного эксперимента. Расчету методом конечных элементов насыпи земляного полотна со слоями, армированными, объемными георешетками, посвящены также работы [11, 12].

Доклады с участием Ю.В. Немировского были представлены и опубликованы в трудах крупных зарубежных международных конференций:

- Третья европейская конференция по применению геосинтетических материалов в строительстве: Еврогео3 (Мюнхен, 2004) [13];

- Восьмая международная конференции по применению геосинтетических материалов в строительстве (Йокогама, 2006) [14]. 


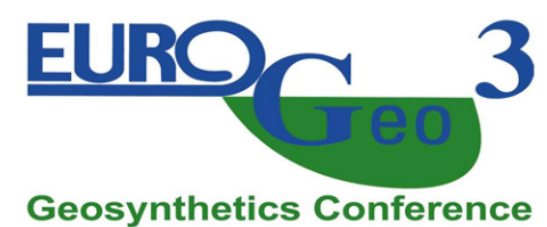

\section{Geotechnical Engineering with Geosynthetics}

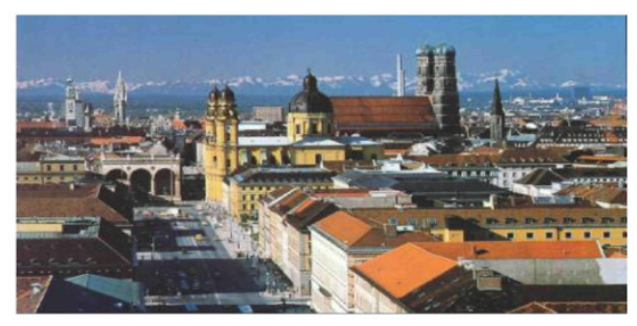

Third

European

Geosynthetics

Conference

Munich, Germany

01 - 04 March 2004
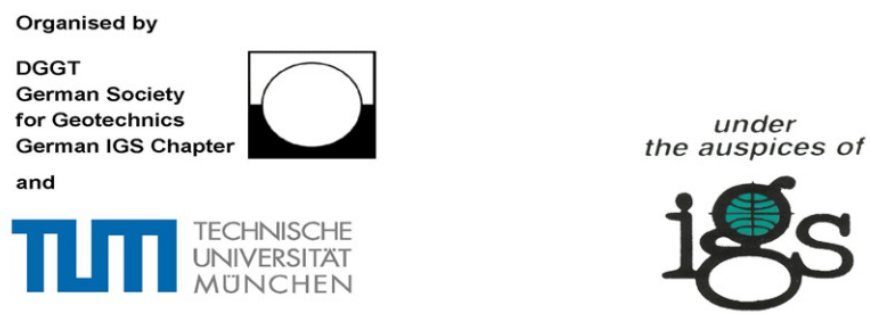

18-22 September 2006,Yokohama,Japan

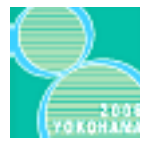

\section{8 th International Conference on Geosynthetics}

Рис. 1.

По результатам проведенных исследований, посвященных разработке теории расчета армированных дорожных конструкций, была опубликована монография [15], которая в 2006 году стала лауреатом Всероссийского конкурса учебников, учебных пособий и монографий по специальности "Автомобильные дороги и аэродромы". В том же году автором этих строк была защищена докторская диссертация на тему "Моделирование и расчет армированных многослойных плит на упругом основании" (научный консультант - д.ф.- м. н., проф. Ю.В. Немировский).

\section{ЛИТЕРАТУРА}

[1] Немировский Ю. В., Матвеев С. А. Построение расчетной модели грунта, армированного объёмной георешеткой // Известия вузов. Строительство. 2002. № 9. С. 95-101.

[2] Матвеев С. А., Немировский Ю. В. Влияние структуры армирования на физико-механические свойства армированного слоя основания дорожной конструкции // Известия вузов. Строительство. 2005, № 1. С. $72-81$. 
[3] Матвеев С. А., Немировский Ю. В. Свойства упругого слоя основания дорожной одежды, армированного объёмной георешеткой // Наука и техника в дорожной отрасли. 2005. № 2. С. 24-28.

[4] Матвеев С. А., Немировский Ю. В. Влияние структуры армирования основания дорожной одежды на его физико-механические свойства // Дороги и мосты. Сборник ГП Росдорнии. 2005. Вып. 13/1. C. $151-162$.

[5] Матвеев С. А., Немировский Ю. В. Теория расчета многослойных дорожных плит, армированных геосинтетическими материалами // Известия вузов. Строительство, 2004. № 6. С. 83-91.

[6] Матвеев С. А., Немировский Ю. В. Теория расчета термоупругих слоистых дорожных плит, армированных геосинтетическими материалами // Югра: дороги в будущее'. 2004. № 1. С. 3031.

[7] Матвеев С. А., Немировский Ю. В. Теория расчета многослойных полиармированных плит на упругом основании / В кн.: Образование, наука и техника: XXI век / Сб. науч. Статей. Выпуск 3. Ханты-Мансийск: Югорский Гос. ун-т. 2005. С. 111-120.

[8] Матвеев С. А., Немировский Ю. В. Расчет многослойных плит, армированных плоскими георешетками / В кн.: Проблемы оптимального проектирования сооружений. Докл. V Bсеросс. Семинара, посвящ. 75-летию НГАСУ (Сибстрин) (7-8апреля 2005 г.). Новосибирск: НГАСУ (Сибстрин). 2005. С. 232-239.

[9] Матвеев С. А., Немировский Ю.В. Расчет многослойных дорожных плит, армированных плоскими георешетками / В кн.: Образование, наука и техника: XXI век. Сб. науч. Статей. Выпуск 3. Югорский Гос. ун-т. Ханты-Мансийск, ЮГУ, 2005. С. 107-111.

[10] Матвеев С. А., Немировский Ю. В. Расчет многослойной армированной дорожной конструкции // Наука и техника в дорожной отрасли. 2005. № 3. С. 28-33.

[11] Немировский Ю. В., Матвеев С. А. , Мартынов Е. А. Расчет грунтового полупространства, армированного объемными георешетками, методом конечных элементов // Труды НГАСУ. Т. 6. №6 (27). 2003. С. 97-103.

[12] Немировский Ю. В. , Матвеев С. А. Расчет НДС насыпи, армированной объёмными георешетками, при низких температурах // Труды II Евразийского симпозиума по проблемам прочности материалов и машин для регионов холодного климат. EURASTRENCOLD-2004. Якутск: ЯФ ГУ "Изд-во СО РАН", 2004. С. 128-133. 